\title{
ASUHAN KEBIDANAN PADA IBU NIFAS HARI KE 10-17 PEMBERAN DAUN KATUK UNTUK MENINGKATKAN P4ODUKSI ASI DI BPM LILIS ZUNIARSIH,A.MD.KEB DESA SEGODOREJO KECAMATAN SUMOBITO KABUPATEN JOMBANG
}

\author{
Midwifery Care On Postpartum Days 10-17 In BPM Lilis Zuniarsih ,A.md.Keb \\ Segodorejo Vllage Sumobito District Jombang District
}

\author{
Karina Emyasari, Septi Fitrah Ningtyas, Sestu Retno Dwi Andayani \\ STIKES Pemkab Jombang \\ Email : Karinaandrianto07@gmail.com
}

\begin{abstract}
ABSTRAK
Pendahuluan : Masa nifas merupakan masa kritis yang dapat menimbulkan masalah jika tidak ditangani dengan segera. Masalah yang sering dialami ibu nifas yaitu proses menyusui. Kegagalan dalam proses menyusui sering disebabkan karena ketidakmampuan ibu menyusui dengan benar, pengeluaran ASI yang tidak lancar menyebabkan nutrisi bayi berkurang. Tujuan penelitian untuk memberikan asuhan kebidanan pada ibu nifas hari ke 10-17 pemberian daun katuk untuk meningkatkan produksi ASI. Metode : Penelitian ini menggunakan metode penelitian kualitatif dalam bentuk studi kasus dengan melakukan pendekatan asuhan kebidanan manajemen varney. Subyek penelitian yang digunakan 2 responden dengan diagnosa kebidanan yang sama yaitu ibu nifas hari ke 10-17. Penelitian dilaksanankan selama 8 hari dengan memberikan asuhan kebidanan pada ibu nifas yang diberikan daun katuk di BPM Lilis Zuniarsih A.md.Keb. Hasil :Hasil penelitian menunjukkan bahwa pada kasus 1 ASI lancar 1 hari setelah diberikan daun katuk sedangkan hasil peneltian yang dilakukan pada kasus 2 ASI lancar 1 hari setelah diberikan daun katuk.Hal ini menunjukkan bahwa dengan diberikannya daun katuk dapat memperlancar produksi ASI pada ibu nifas.Pembahasan : Dapat disimpulkan asuhan kebidanan nifas normal dapat diatasi apabila diberikan daun katuk. Saran untuk ibu nifas yaitu menyusui sesering mungkin dan diberikan daun katuk untuk meningkatkan produksi ASI.
\end{abstract}

Kata Kunci : Nifas Fisiologis 10-17, Asuhan Kebidanan

\begin{abstract}
Introduction : The puerperium is a critical period that can cause problems if not adressed immediately. A problem that is often experienced by postpartum breastfeeding. Failure in the breast feeding process is often due to the inability of the mother to breasfeed properly, the discharge of breast milk that is not fluent causes the baby's nutrition is reduced. The purpose of the study was to provide midwifery care to postpartum mothers 10-17 katuk leaves to increase milk production. Method :This research uses qualitative research methods in the form of case studies by approaching the management of varney management midwifery care. Subjects used 2 respondents with varney management obstetrics. Subjects of the study used 2 respondents with the same midwifery diagnosis of postpartum day 10-17. Research was conducted for 8 days by giving midwifery care to postpartum mother given katuk leaf at bpm lilis zuniarsih A.md,Keb. Result : The results showed that in the case of 1 breast milk smoothly 1 day after being given katuk leaves while the results of research conducted on the case of 2 breast milk smoothly 1 day after being given katuk leaves.This shows that with the provision of katuk leaves to facilitate the production of breast milk in the postpartum mother.Discuss : It can be concluded normal postpartum care can be overcome when given katuk leaf. Advice for postpartum breastfeeding as often as possible and given katuk leaves to increase milk production of mother's milk.
\end{abstract}

Keyword: Post Partum 10-17, Midwifery Care

PENDAHULUAN

ASI merupakan makanan yang pertama, utama, dan terbaik bagi bayi, yang bersifata ilmiah. ASI mengandung berbagai zat gizi yang dibutuhkan dalam proses pertumbuhan dan perkembangan bayi. Terkait isu, ada suatu hal yang perlu disayangkan, yakni rendahnya pemahaman 
ibu, keluarga, dan masyarakat mengenai pentingnya ASI bagi bayi. Akibatnya, program pemberian ASI Ekslusif tidak berlangsung secara optimal. (Prasetyono, 2009).

ASI Ekslusif menurut World Health Organitation (WHO,2011) adalah memberikan makanan dan minuman lain kepada bayi sejak lahir sampai berumur 6 bulan, kecuali obat dan vitamin. Menurut Riskesdas 2013, adalah proses mulai menyusui terbanyak terjadi pada 1-6 jam setelah kelahiran $(35,2 \%)$ dan kurang dari 1 jam (inisiasi menyusui dini) sebesar 34,5\%. Sedangkan proses mulai menyusui terendah terjadi pada 7-23 jam setelah kelahiranya itu sebesar $3,7 \%$.

ASI Matur adalah ASI yang disekresi pada hari ke 10 sampai seterusnya, ASI matur tampak berwarna putih . kandungan ASI matur relatif konstan, tidak menggumpal bila dipanaskan. Manfaat ASI matur : forenmilk lebih encer mempunyai kandugan rendah lemak, dan tinggi laktosa, gula, protein, mineral dan air. Hindmilk membuat bayi akan lebih cepat kenyang mngandung kaya akan lemak dan nutrisi.

Cakupan ASI Eksklusif tertinggi di

Puskesmas Bawangan (98,59\%), Kabuh (98,05\%), Blimbing Gudo (97,87\%). Sedangkan cakupan terendah ada di Puskesmas Pulolor $(66,04 \%)$,Kesamben Ngoro $(67,91 \%)$, dan Peterongan $(69,62 \%)$. Cakupan ASI Eksklusif di Kabupaten Jombang Tahun 2010-2014.(Sumber: Seksi Gizi Dinkes Kab. Jombang), Capaian ASI Eksklusif selama lima tahun terakhir memiliki tren naik, nilai tertinggi pada tahun $2014(79,87 \%)$ dan terendah tahun 2010 $(53,5 \%)$.

Cakupan pemberian ASI Ekslusif pada bayi umur 0-6 bulan menurut provinsi tahun 2015 (Sumber: Ditjen Kesehatan Masyarakat, Kemenkes RI, 2016). Mengacu pada target renstra pada tahun 2015 yang sebesar 39\%, maka secara nasional cakupan pemberian ASI eksklusif pada bayi usia kurang dari enam bulan sebesar 55,7\%telah mencapai target.

Ada beberapa faktor yang mempengaruhi penggunanaan ASI Ekslusif diantaranya perubahan social budaya, faktor psikologis, factor fisik ibu, factor kurangnya petugas kesehatan, meningkatkan promosi susu formula, penerangan yang salah justru datangnya dari petugas kesehatan sendiri yang menganjurkan penggantian ASI dengan susu formula.

Daun katuk termasuk anggota dari family euphorbiaaceae. Di indonesia, katuk tumbuh subur pada ketinggian 0-2.100 m dpl. Tanaman ini berupa perdu, yang tingginya mencapai 2-3 m. Cabang-cabangnya agak lunak, daun tersusun berselang-seling pada satu tangkai, serta berbentuk lonjong sampai bundar dengan panjang kira $2,5 \mathrm{~cm}$ dan lebar $1,25-3 \mathrm{~cm}$. Sedangkan buahnya berbentuk bulat pada cabang-cabang di bawah daun.

Di indonesia, daun katuk digemari oleh para ibu untuk melancarkan air susu ibu (ASI), mengobati bisul, demam, serta borok. Selain memperlancar dan meningkatkan produksi ASI, daun katuk yang populer sebagai sayur ini bias juga membangkitkan vitalitas seksual, mencegah osteoporosis, dan mengobati bermacam-macam penyakit.

\section{METODE PENELITIAN}

Penelitian ini menggunakan teknik asuhan kebidanan berupa studi kasus. Studi kasus adalah karya tulis ilmiah berupa paparan hasil penerapan proses asuhan kebidanan kepada klien secara ideal sesuai dengan teori dan berisi pembahasan atas kesenjangan yang terjadi di lapangan sesuai dengan 5 langkah manajemen Varney. Data diambil dari sumber lapangan pada pasien atau keluarga pasien yaitu ibu bersalin yang melahirkan di BPM Lilis Zuniarsih, A.md.Keb Desa Segodorejo Kecamatan Sumobito, Kabupaten Jombang. Ibu nifas hari ke 10-17 pemberian daun katuk untuk meningkatkan produksi ASI selama 8 hari berturut-turut.

Responden pada penelitian ini adalah 2 pasien dengan diagnosa kebidanan yang sama, yaitu ibu nifas fisiologis hari 10-17 yang bersedia menjadi subyek penelitian.

Metode pengumpulan data yang digunakan adalah

a) Wawancara (hasil anamnesa) berisi tentang identitas pasien, keluhan utama, riwayat penyakit sekarang, riwayat penyakit dahulu, riwayat penyakit keluarga, pola kebiasaan sehari - hari. Sumber data yang diperoleh dari pasien, keluarga, dan bidan. Kemudian hasil wawancara atau anamnesis ditulis 
dibuku catatan kemudian di salin di format pengkajian pasien.

b) Observasi dan pemeriksaan fisik dengan pendekatan IPPA (inspeksi, palpasi, perkusi, dan auskultasi) secara head to toe. Kemudian hasil observasi ditulis dalam buku catatan yang selanjutnya disalin dalam lembar pengkajian pasien

c) Studi dokumentasi yaitu memperoleh data dari hasil pemeriksaan diagnostic dan rekam medis pasien. Prosedur analisa data yang digunakan adalah dengan menarasikan data yang diperoleh selama wawancara dan observasi untuk diinterpretasikan peneliti

d) dibandingkan dengan teori yang ada guna memberikan rekomendasi dalam intervensi yang diberikan.

\section{PEMBAHASAN}

\section{Pengkajian}

Data di atas yang mencakup identitas, fakta bahwa ibu nifas hari ke 10-17. Dari riwayat kesehatan di dapatkan kedua pasien tidak menderita penyakit menurun (diabetes, hipertensi), menahun (jantung, ginjal, kanker), ataupun menular (HIV, TBC, dll). Saat ini pada pasien 1 dan 2 merupakan kehamilan Pertama. Kedua Pasien mengatakan tidak pernah menggunakan KB apapun. Pemeriksaan umum yang dilakukan menunjukkan hasil normal, begitu juga dengan pemeriksaan fisik.

Pada pasien 1 dan 2 mengatakan saat ini ASI-nya keluar sedikit secara teori tidak sedikit ibu nifas mengeluhkan ASInya keluar sedikit atau tidak lancar dikarenakan faktor nutrisi dan hisapan. Oleh karena itu diberikan terapi daun katuk untuk meningkatkan produksi ASI ( Ambarwati,2010).

Dapat disimpulkan bahwa secara keseluruhan pada pengkajian data subyektif dan obyektif pada kedua responden diats merasakan keluhan yang hampir sama, antara teori dan keadaan sebenarnya sama.

\section{Diagnosis Kebidanan}

Data yang diperoleh dari pengkajian diruangan terhadap responden 1 dan 2 P10001 ibu nifas hari ke 10. Secara teori tidak sedikit ibu akan mengeluh pengeluaran ASI yang tidak lancar.

ASI yang tidak lancar akan mempengaruhi kebutuhan nutrisi pada bayi. Oleh karena itu diberikan terapi daun katuk untuk meningkatkan produksi ASI (Ambarwati,2010).

Daun katuk termasuk anggota dari family euphorbiaaceae. Di indonesia, katuk tumbuh subur pada ketinggian 0-2.100 m dpl. Tanaman ini berupa perdu, yang tingginya mencapai 2-3 m. Cabang-cabangnya agak lunak, daun tersusun berselang-seling pada satu tangkai, serta berbentuk lonjong sampai bundar dengan panjang kira 2,5 $\mathrm{cm}$ dan lebar 1,25-3 cm. Sedangkan buahnya berbentuk bulat pada cabangcabang di bawah daun.

Di indonesia, daun katuk
digemari oleh para ibu untuk melancarkan air susu ibu (ASI), mengobati bisul, demam, serta borok. Selain memperlancar dan meningkatkan produksi ASI, daun katuk yang populer sebagai sayur ini bias juga membangkitkan vitalitas seksual, mencegah osteoporosis, dan mengobati bermacam-macam penyakit (Yusari,2013).

\section{Intervensi Kebidanan}

Berdasarkan hal tersebut intervensi yang diberikan adalah 1) Lakukan observasi tekanan darah, nadi, suhu, pernapasan, TFU, kontraksi uterus, kandung kemih dan perdarahan. 2) Menjelaskan hasil pemeriksaan kepada ibu. 3) Ajari ibu tentang perawatan payudara. 4) Anjurkan ibu untuk memperbanyak mengkonsumsi daun katuk < 300 gram. 5) Jelaskan pada ibu untuk menyusui bayinya dengan sering. 6) Ajari ibu cara memerah ASI dan cara penyimpanan ASI.7) Berikan motivasi ibu dalam memberikan ASI.8) Berikan KIE tentang personal hygiene.9) Berikan KIE tentang nutrisi seimbang untuk ibu nifas, anjurkan diet tinggi protein, tinggi karbohidrat.

\section{Implementasi Kebidanan}

Implementasi yang dilakukan pada kedua responden tidak terdapat 
perbedaan. Dimana responden 1 dan 2 mendapat perlakuan yang sama yaitu peneliti memberikan terapi daun katuk dan kie asi ekslusif.

\section{Evaluasi Kebidanan}

Pada evaluasi didapatkan hasil bahwa setelah diberikan intervensi pada kasus 1 dan 2 ibu mengatakan ASI-nya sudah keluar dengan lancar pada hari ke 11.

\section{KESIMPULAN DAN SARAN}

\section{Kesimpulan}

Kesimpulan dari penelitian ini adalah menunjukkan bahwa dalam kasus ASI keluar sedikit dapat teratasi bila diberikan terapi daun katuk. Sehingga ASI dari kedua dapat keluar lancar dan kedua responden dapat menyusui dengan tenang.

\section{Saran}

Berdasarkan hasil asuhan kebidanan saran yang dapat diberikan adalah sebagai berikut :

\section{a. Bagi Peneliti Selanjutnya}

Dengan asuhan yang sudah diberikan agar dapat digunakan sebagai informasi dasar mengenai gambaran asuhan kebidanan pada ibu nifas hari 10-17 pemberian daun katuk serta diharapkan pada peneliti selanjutnya mencari informasi terbaru terkait frekuensi daun katuk, dikarenakan didalam teori yang digunakan peneliti saat ini belum disebutkan frekuensi daun katuk, melainkan hanya disebutkan bahwa daun katuk dapat dilakukan berulang ulang.

b. Bagi Bidan

Dengan asuhan yang sudah diberikan agar dapat digunakan sebagai masukan pada tenaga kesehatan untuk dapat diterapkan dalam asuhan kebidanan pada ibu bersalin salah satunya dengan memberikan daun katuk untuk untuk meningkatkan produksi ASI.

\section{DAFTAR PUSTAKA}

A.Aziz Hidayat, 2007, Riset Keperawatan dan Teknik Penulisan Ilmiah, Salemba Medika, Jakarta.
Abidin, Muhammad Zainal. 2011. Asuhan Postnatal Care. www.masbied.com/ search/ pembagian- umur-menurutmasa-reproduksi diakses tanggal 04/06/2012, jam 5:57

Ambarwati, Eny Retna. 2010. Asuhan Kebidanan Nifas. Jogjakarta: Nuha Medika

Arikunto, Suharsimi. 2006. Prosedur Penelitian Suatu Pendekatan Praktik. Jakarta : Rineka Cipta

Azwar, Azrul. 2008. Buku Acuan Asuhan Persalinan Normal dan Inisiasi Menyusu Dini Revisi 2007. Jakarta : JNPK-KR.

Bahiyatun. 2009. Buku Ajar Asuhan Kebidanan Nifas Normal. Jakarta : EGC.

Depkes. RI. 2009. Penanganan Fasilator Kelas Ibu Hamil. Jakarta

Djitowiyono, Sugeng, dkk. 2010. Asuhan Keperawatan Neonatus Dan Anak. Yogyakarta : Nuha medika.

Friedman. 2004. Keperawatan Keluarga. Jakarta : EGC.

Kelly, Paula. 2010. Buku Saku Asuhan Neonatus \& Bayi. Jakarta : EGC.

Keperawatan. Yogyakarta: Nuha Medika

Kristiyansari, Weni. 2010. Nuha Medika. Yogyakarta

Maryunani, Anik. 2012. Inisiasi Menyusu Dini, ASI Ekslusif Dan Manajemen Laktasi. Jakarta : CV. Trans Info Medika.

Nazir, Moh. 2009, Metode Penelitian, Bogor: Ghalia Pustaka.

Notoatmodjo, Soekidjo. 2003. Pendidikan dan Perilaku Kesehatan. Jakarta: Rineka Cipta

Notoatmodjo, Soekidjo. 2010. Metodologi Penelitian Kesehatan. Jakarta: Rineka Cipta.

Nursalam. 2009. Konsep dan Penerapan Metodologi Penelitian Ilmu Keperawatan. Jakarta: Salemba Medika. 
Pertiwi., P. 2012. Gambaran Faktor-Faktor Yang Mempengaruhi Pemberian ASI Ekslusif Di Kelurahan Indah Tangerang. Skripsi. Universitas Indonesia.

Prasetyono.2012. Buku Pintar ASI Ekslusif. Yogya : Diva Press

Prawirohardjo, Sarwono. 2009. Ilmu Kebidanan. Jakarta: BPSP.

Purwanti, Sri Hubertin. 2004. Konsep Penerapan ASI Eksklusif. Jakarta : EGC.

Reeder, Sharon j. 2011. Keperawatan Maternitas: Kesehatan Wanita, Bayi \& Keluarga. Jakarta: EGC

Saleha, sitti. 2009. Asuhan Kebidanan Pada Masa Nifas. Jakarta : Salemba Medika.

Saleha, Sitti. 2010. Asuhan Kebidanan pada Masa Nifas. Jakarta: Salemba Medika

Saminem, Hajjah. 2009. Seri Asuhan Kebidanan Kehamilan Normal. Jakarta : EGC.
Simkin, Penny, dkk. 2008. Panduan Lengkap Kehamilan, Melahirkan, dan Bayi. Jakarta : Arcan.

Sugiyono, 2009, Metode Penelitian Pendidikan, Alfabeta, Bandung.

Suherni, dkk. 2008. Perawatan Masa Nifas. Yogyakarta : Fitramaya.

Sulistyawati, ari.2009. Buku Ajar Asuhan Kebidanan Pada Ibu Nifas. Jogjakarta. Andi Offset.

Sunaryo. 2004. Psikologi Untuk Keperawatan. Jakarta :EGC

Suradi, Rulina, dkk. 2004. Bahan Bacaan Manajemen Laktasi. Jakarta: Perkumpulan Perinatalogi Indonesia.

Varney. 2006. Buku Ajar Asuhan Kebidanan. Jakarta : EGC.

Yesie, Aprillia. 2010. Hipnostetri Rileks, Nyaman, dan Aman Saat Hamil \& Melahirkan. Jakarta : Gagas Media.

Yuliarti, Nurheti. 2010. Keajaiban ASI. Yogyakatra : Andi Yogyakarta 